\title{
ПЕРЕДАЧА ТА ПЕРЕХІД ПАЦІЄНТІВ 3 ЮВЕНІЛЬНИМ ІДІОПАТИЧНИМ АРТРИТОМ ВІД ДИТЯЧОГО ДО ДОРОСЛОГО РЕВМАТОЛОГА
}

\author{
Я. Є. Бойко, О. В. Підкова ${ }^{2}$ \\ ${ }^{1}$ Тернопільський національний медичний університет \\ імені І. Я. Горбачевського МОЗ Украӥни \\ ${ }^{2}$ Комунальне некомерційне підприємство Львівської обласної ради \\ «Західноукраӥнський спеціалізований дитячий медичний центр»
}

У статті описано необхідність цілеспрямованого запланованого переходу підлітків, хворих на ювенільний ідіопатичний артрит, від дитячого до дорослого ревматолога. Описано елементи підготовки, планування та проблеми, які виникають у перехідний період.

\section{TRANSMISSION AND TRANSITION OF PATIENTS WITH JUVENILE IDIOPATHIC ARTHRITIS FROM PEDIATRIC TO ADULT RHEUMATOLOGIST}

\author{
Ya. E. Boykoํㅜ, O. V. Pidkova ${ }^{2}$ \\ ${ }^{1}$ I. Horbachevsky Ternopil National Medical University \\ ${ }^{2}$ Western-Ukrainian Specialized Children's Medical Centre
}

The article describes the necessity of purposeful and planned transition of adolescents with JIA from pediatric to adult rheumatologists. The article provides elements of education, planning, and problems that arise during the transition period.

Вступ. Перехід підлітків/молодих людей, хворих на ювенільний ідіопатичний артрит (ЮІА), від дитячого до дорослого ревматолога - це не простий перехід, це скоординовані дії, спрямовані на інтеграцію пацієнта від системи охорони здоров'я, орієнтованої на дитину та сім'ю, до системи надання медичних послуг, які спрямовані на дорослих. Метою цього переходу $\epsilon$ розширення можливостей пацієнта брати на себе відповідальність за власне здоров'я та спосіб свого життя, що надалі забезпечить надання високоякісної медичної допомоги цим пацієнтам у дорослому житті [1].

Основна частина. Коли дорослий ревматолог починає опікуватися пацієнтом, хворим на ЮІА, він повинен враховувати всі фактори, які впливають як на фізичне здоров'я, так і на психосоціальний статус хворих. До проблем, які пов'язані з фізичними розладами у хворих на ЮІА, насамперед належать розлади росту, особливо локальні (наприклад, різна довжина уражених кінцівок), або зміни, зумовлені затримкою росту. До інших проблем фізичного здоров'я пацієнтів

(с) Я. Є. Бойко, О. В. Підкова, 2020 із ЮІА належать порушення статевого дозрівання, функціональні наслідки хвороби, що можуть призвести до функціональної втрати працездатності, наслідки увеїту різного ступеня тяжкості (зокрема катаракта, глаукома, втрата зору), остеопороз та/або остеонекроз внаслідок тривалого приймання гормонів, часті інфекції, викликані довгочасним застосуванням базових препаратів, що пригнічують загальну імунну відповідь [2].

У підлітків із ЮІА часто розвиваються психосоціальні проблеми, що призводять до недостатньої самостійності пацієнтів через функціональні наслідки хвороби. Все це впливає на професійну діяльність, щоденне та суспільне життя. У підлітків, які хворіють на ЮІА, через надмірне психологічне навантаження часто розвивається виражена тривожність або депресія. Тому, окрім проблем, пов'язаних із самих захворюванням, дорослий ревматолог має справу з підлітком чи молодою людиною, яку запрошують взяти участь у абсолютно іншій моделі співпраці пацієнта з лікарем. Йдеться про зміну системи надання медичних послуг від сімейно-орієнтованої до пацієнт-орієнтованої, що 
призводить до зміни звичного способу життя молодої особи, появи нового середовища з новими правилами $[2,3]$. Це може асоціюватися з появою тривоги та ставить нові виклики перед хворими на ЮІА. Крім того, дуже революційний період цієї вікової групи підлітків може призводити до суперечок із лікарями щодо їхніх призначень та має ризик завершитися недотриманням лікування чи правил регулярного спостереження. Таким чином, лікар повинен успішно лікувати цих молодих людей із ЮІА, проявляючи терпіння та доброзичливість, виділяючи достатньо часу на діалог та пояснення.

Хоча найвідповіднішим періодом для початку формального процесу переходу $є$ підлітковий вік, підготовка до переходу може розпочинатися раніше. Необхідно у розмовах зі сім'єю забезпечити достатньо часу для того, щоб родина усвідомила необхідність переходу дитини під спостереження інших спеціалістів. Процес переходу $є$ сімейним процесом. Сім'я відіграє у ньому вирішальну роль і повинна підтримувати та заохочувати дитину при розгляді майбутніх очікувань щодо освіти, працевлаштування та самостійного життя з урахуванням наявності хвороби. «Бачення» майбутнього, коли дитина сама почне опікуватися власними медичними проблемами, починаючи 3 раннього дорослого віку, стане мотивацією для належної підготовки пацієнта. Під час медичних візитів до дитячого ревматолога необхідно обговорювати 3 дитиною питання, які стосуються діагностики, лікування та віддалених наслідків її захворювання. Варто пересвідчитися, що пацієнт розуміє суть хвороби, значення та механізми дії медикаментів, які приймає. У підлітковому віці розмови повинні зосереджуватися на необхідності проведення моніторингу хвороби з візитами до ревматолога та важливості регулярного приймання медикаментів, дотримання здорового способу життя. Крім того, потрібно інформувати підлітка, який хворіє на ЮІА, з таких питань, як інфекції, вакцинація, вплив ЮІА на сексуальну поведінку та вагітність [4].

Підготовка пацієнта до відповідальності за власне здоров'я $\epsilon$ тривалим процесом, який повинен розпочинатися у ранньому дитинстві та продовжуватися в дорослому віці з метою розвинути навички самообслуговування, необхідні для незалежного фізичного і психосоціального життя, потрібні нащодень у дорослому віці - для здійснення подорожей, керування вільним часом, дружби, освіти, майбутнього працевлаштування. Крім того, пацієнт повинен мати можливість виконувати рекомендації лікаря щодо спостереження та лікування захворювання, вміти самостійно керувати появою болю, втоми та надзвичайними ситуаціями, які може спричинити ця хвороба.

Як планувати процес переходу для пацієнтів, хворих на ЮІА?

Крок 1. Дитячий ревматолог повинен поговорити з батьками дитини, у якої підтверджений діагноз ЮІА, про перебіг захворювання. Можна рекомендувати надійні джерела, такі, як сайт PRINTO (Міжнародна організація випробувань педіатричної ревматологіï, http://www.printo.it/pediatric-rheumatology/), де $\epsilon$ об'єктивна інформація про захворювання.

Крок 2. Поступове навчання пацієнта з ЮІА (щодо перебігу захворювання, його ускладнень, наслідків, оцінки якості життя). Важливими є регулярні візити до лікаря з виділенням лікуючим лікарем додаткового часу для формування довірчих стосунків між ним та сім'єю. Все це є передумовою успішного лікування та переходу до дорослих спеціалістів.

Крок 3. Потрібно обговорювати з батьками план навчання та занять дитини. Крім того, необхідно заохочувати співпрацю родини з іншими фахівцями (психологами, професійними консультантами) для забезпечення найоптимальнішого варіанта вибору, майбутньої професії для кожного пацієнта з ЮІА.

Крок 4. Необхідно проводити постійну підготовку та навчання пацієнтів із ЮІА з метою розвитку навичок самообслуговування для самостійного життя. Важливою $є$ участь дітей у таких групових заходах поза межами дому, як літні табори під наглядом лікаря та спеціаліста-фізіотерапевта.

Підліткові з ЮІА для успішного переходу від дитячого до дорослого ревматолога необхідні певні знання та навички.

І. Знати:

- суть захворювання та важливість лікування хвороби;

- ризики від недотримання лікарських рекомендацій;

- специфічні проблеми, пов'язані з ЮІА, наприклад - інфекції, щеплення;

- фінансування лікування;

- здоровий спосіб життя;

- вплив залежності (алкогольної, наркотичної) на результат лікування ЮІА;

- вплив ЮІА на сексуальне здоров'я, сімейне життя та вагітність;

- навчання, професійну зайнятість. 
II. Навички, необхідні для переходу від дитячого до дорослого ревматолога:

- незалежність від батьків у керуванні лікувальним процесом ЮІА;

- вміння проводити пошук медичної інформації;

- співпраця з новим медичним колективом;

- дотримання рекомендацій та процедур, пов'язаних із захворюванням;

- забезпечення навичок керування болем, стресом, надзвичайними ситуаціями;

- незалежне фізичне та психосоціальне життя (здійснення подорожей, керування вільним часом, дружба, освіта чи працевлаштування).

Співпраця пацієнта, хворого на ЮІА, його сім'ї, лікуючих лікарів та лікарів системи охорони здоров'я $\epsilon$ необхідною умовою для здійснення успішного переходу до дорослого спеціаліста.

План переходу від дитячого до дорослого спеціаліста повинен бути гнучким, з визначенням оптимального терміну його реалізації. Час виконання переходу має враховувати емоційну та фізичну зрілість пацієнта. Підлітка потрібно залучати до планування перехідного періоду, заохочувати його ділитися власними поглядами щодо питань якості життя, фізичних обмежень, соціальних відносин, у тому числі з лікарями, які надалі будуть проводити його спостереження [5].

Перехід повинен відбуватися, коли дитячий ревматолог впевнений в тому, що підліток здатний самостійно приймати рішення з питань щодо власного здоров'я та вміє керувати процесом лікування, незалежно від сім'і та педіатра. При розробці програми переходу варто враховувати успішність підлітка та труднощі у навчанні, поведінкові проблеми, наявність гіперактивних розладів та інших психологічних проблем, які можуть заважати можливості брати відповідальність за власне здоров'я. Дуже корисно залучати до процесу переходу та передачі молодих людей із ЮІА, які вже інтегровані в дорослу ревматологічну клініку, оскільки вони зможуть підтримати нових пацієнтів, які ще перебувають на перехідному етапі процесу переходу.

Потрібно обговорювати з підлітком, який хворіє на ЮІА, майбутній вибір професії. Підліток повинен вибрати професію, яка буде не тільки цікавою, але й сумісною з його фізичною активністю та духовним потенціалом. Батьки та пацієнти повинні бути поінформовані про обмеження, зумовлені захворюванням, його впливом на працездатність. Така підготовка призначена для того, щоб дитина вибрала той фах, ту кар'єру, яку зможе реалізувати протягом усього свого життя. Дослідження показали, що пацієнти з ЮІА успішні, як і здорові ровесники. 3 іншого боку, серед пацієнтів на ЮІА $є$ вищим рівень безробіття, дискримінація на робочому місці, труднощі в підтримуванні зайнятості під час загострень хвороби, часті зміни місця праці через фізичну дисфункцію.

Медичні документи, які готує дитячий ревматолог для передачі пацієнта, мають містити: виписку з повною історією хвороби, даними про вік дебюту хвороби, варіант перебігу захворювання, фенотип ЮІА (які суглоби були уражені, лабораторний профіль - ANA, RF, HLA), а також заключення окуліста. У виписці має бути інформація про раніше застосоване лікування та його ефективність, перебіг захворювання з інформацією про загострення хвороби та терапію, яка була використана під час цих епізодів. Під час останнього візиту пацієнта з ЮІА необхідно оцінити стан хвороби підлітка з використанням таких валідизованих ревматологічних інструментів, як оцінка активності хвороби за JADAS, результати лікування (ACR pedi) та функціональні можливості пацієнта за CHAQ чи JAMAR [6].

Потрібно повідомити дорослого спеціаліста про можливі інші супутні захворювання та їх вплив на здоров'я пацієнта. Важливо також поінформувати його про психосоціальний стан пацієнта та його персональні характеристики (проблеми/фобії, впевненість чи невпевненість, уподобання), а також про академічні досягнення та професійну орієнтацію.

Згідно з міжнародними рекомендаціями, для успішного процесу переходу є обов'язковим залучення батьків та дитини, а також дорослого та дитячого ревматолога. Дуже корисною вважають участь сімейного лікаря, педіатра та/або іншого лікаря, який бере участь у лікувальному процесі (наприклад, для вирішення питань проведення вакцинації, для контролю за артеріальним тиском, холестерином, для консультування щодо харчування, контрацепції, сексуальності). Дорослий та дитячий ревматолог мають обговорити дані пацієнта з медичної виписки, наданої дорослому ревматологу. Процес переходу спрощує залучення координатора медичного переходу, функцію якого можуть виконувати інші медичні працівники, зокрема спеціалізовані медичні сестри.

Висновки. Процес переходу підлітка, хворого на ЮІА, до дорослого ревматолога $\epsilon$ активним, динамічним та гнучким процесом, адаптованим відповідно до віку, розумового, фізичного та культурного розвитку пацієнта. Процес передачі пацієнта з ЮІА 
має враховувати його фізичний та психосоціальний статус, освіту та професійну реабілітацію. Цей процес має бути своєчасним, орієнтованим на майбутнє пацієнта. Необхідними умовами успішної передачі

\section{СПИСОК ЛІТЕРАТУРИ}

1. Бойко Я. Є. Ювенільний ідіопатичний артрит : монографія / Я. Є. Бойко, В. П. Чернишов ; за ред. Я. Є. Бойко. 2-ге вид., доповн. - Львів : Світ, 2019. - С. 10-25, 212-220.

2. Khuffash F. A. Epidemiology of juvenile chronic arthritis and other connective tissue diseases among children in Kuwait / F. A. Khuffash, H. A. Majjed [et al.] // Ann. Trop. Paediatr. - 1990. - Vol. 10. - P. 255-259.

3. Steven M. M. Prevalence of chronic arthritis in four geographical areas of the Scottish Highlands / M. M. Steven // Ann. Rheum. Dis. - 1992. - Vol. 51. - P. 195-197.

4. International League of Associatiation for Reumatology classification of juvenile idiopathic arthritis: second revision, $\epsilon$ оволодіння навичками спілкування, прийняття рішень та керування власним здоров'ям. Лише за таких умов перехід може бути успішним.

Edmonton, 2001 / R. E. Petty, T. R. Southwood, P. Manners [et al.] // J. Rheum. - 2004. - Vol. 31 (2). - P 390-392.

5. Nigrovic P. A. Review: Genetics and the classifi cation of arthritis in adult and children / P. A. Nigrovic, S. Raychaudhuri, S. D. Thompson // Arthritis Rheum. (Hoboken, Nj). - 2018. Vol. 70 (1). - P. 7-17.

6. EULAR/Pres standards and recommendations for the transitionalcare of young people with juvenile-onset rheumatic diseases / H. E. Foster, K. Minden, D. Clemente [et al.] // Ann. Rheum. Dis. - 2016. - Vol. 76 (4). - P. 639-646.

Отримано 28.02.20 